\title{
Gonadotrophin-induced follicle development in red deer hinds during the breeding and non-breeding seasons
}

\author{
B. J. McLeod ${ }^{1}$, L. M. Meikle' ${ }^{1}$, M. W. Fisher ${ }^{1}$, G. H. Shackell ${ }^{1}$ \\ and D. A. Heath ${ }^{2}$ \\ ${ }^{1}$ AgResearch, Invermay Agricultural Centre, Private Bag 50034, Mosgiel, New Zealand; and \\ ${ }^{2}$ Wallaceville Animal Research Centre, PO Box 40063, Upper Hutt, New Zealand
}

The effect of exogenous equine chorionic gonadotrophin (eCG) and endogenous (GnRH-treatment) gonadotrophins in promoting antral follicle development in red deer hinds was assessed during the breeding and non-breeding seasons. After progesterone pretreatment, hinds received no further treatment, a single injection of 300 iu equine chorionic gonadotrophin or infusion of $\mathrm{GnRH}\left(1.0 \mu \mathrm{g} \mathrm{h}^{-1}\right)$ for up to 4 days. Ovaries were recovered ( $n=5$ per group) at the time of, or $36 \mathrm{~h}$ after, progesterone removal. All follicles $\geqslant 2.0 \mathrm{~mm}$ in diameter were dissected out, their health status assessed and follicular fluid oestradiol content measured. Granulosa cells were counted and their capacity for oestradiol and cAMP production assessed in vitro. Oestrus, the preovulatory LH surge and ovulation rates were monitored in additional groups of hinds that had been treated identically ( $n=5$ per group). During the breeding season, all monitored animals ovulated, but five of 15 (one eCG, three GnRH, one progesterone alone) did not exhibit oestrus, and three (all eCG) had luteinized follicles. During seasonal anoestrus, four hinds (all eCGtreated) displayed oestrus, but only two ovulated. Two non-ovulating hinds (one eCG, one progesterone alone) had luteinized follicles. The total number of follicles, or of large $(\geqslant 4 \mathrm{~mm})$ follicles, did not differ significantly between seasons. There were proportionately more healthy follicles during seasonal anoestrus $(P<0.05)$. Treatment with GnRH, and to a lesser extent eCG, increased the number of oestrogenic follicles and their follicular fluid oestradiol content. In summary, exogenous and endogenous gonadotrophins affected antral follicle development similarly in both the breeding and nonbreeding seasons, although the response was variable among animals and often associated with failure of oestrous expression, ovulation and with follicle luteinization.

\section{Introduction}

Red deer (Cervus elaphus) are adapted to mixed browsing and grazing (Hoffman, 1985) and have evolved a breeding strategy that copes with seasonal extremes in food supply and quality (Lincoln and Short, 1980). Under farmed conditions in managed pastoral environments, there is considerable misalignment between seasonal breeding in red deer and the seasonal peak of pasture production and quality. In New Zealand, for example, the spring flush of pasture growth occurs in August-October, but red deer hinds calve naturally in November-December (Asher et al., 1996). Thus, peak demands for lactation and the requirements of the young calf for high quality feed occur in late summer when pasture growth and quality is limited and senescence is occurring in pasture plants.

A number of strategies have been used to control breeding in deer with the aim of better aligning calving and the onset of lactation with pasture growth, by inducing ovulation and mating during seasonal anoestrus. These

*Correspondence.

Email: bernie.mcleod@agresearch.co.nz treatments, which typically involve the administration of exogenous gonadotrophic hormones, have also been used to synchronize oestrus during the breeding season or to induce superovulation. However, the responses have been variable and unpredictable in deer, with some hinds failing to ovulate and with widely varying ovulation rates in those that did ovulate (Fennessey et al., 1994; Asher et al., 1995).

In other ruminants that, like red deer, ovulate a single follicle at each oestrous cycle (for example, cows and some breeds of sheep), a number of growing antral follicles enter a growth phase early in the follicular phase of the oestrous cycle. However, only a single follicle completes preovulatory development and ovulates, with the remainder undergoing atretic degeneration (Hirschfield, 1991). The development of this single dominant follicle suppresses the growth and results in atresia of the other large antral follicles present (McNatty et al., 1982; McNatty and Henderson, 1987). The inclusion of antral follicles into the cohort of rapidly growing follicles early in the follicular phase (termed 'selection' or 'cyclic recruitment') is known to be under the influence of FSH (for review, see McGee and Hseuh, 2000). The administration of exogenous FSH or FSH-like gonadotrophins during the follicular phase will induce superovulation in monovular animals, presumably 
by increasing the number of antral follicles recruited into the growing pool or preventing their degeneration. Equine chorionic gonadotrophin (eCG) is used widely as a source of exogenous gonadotrophin to stimulate superovulation in monovular species. In sheep, eCG increases the numbers of antral follicles $\geqslant 3 \mathrm{~mm}$ in diameter (Dott et al., 1979) and, when administered at the time of luteolysis, eCG prevents the occurrence of atresia in large follicles and enhances their capacity to produce oestradiol (McNatty et al., 1982).

Equine chorionic gonadotrophin has long been used to induce ovulation in seasonally anoestrous ruminants, including deer, but as occurs in the breeding season, ovulation rates in response to this treatment are sometimes extremely variable (red deer: Adams et al., 1985; fallow deer: Asher and Smith, 1987). An alternative approach has been to treat seasonally anoestrous animals with $\mathrm{GnRH}$ administered as either a series of injections or as a continuous infusion to promote endogenous gonadotrophin secretion. In sheep, this approach has proved consistently reliable and has induced ovulation rates comparable to those occurring in the same flock during the breeding season (McLeod et al., 1982, 1983). Similar treatment regimens have been used in Père David's deer (McLeod et al., 1991) and in red deer (Fisher et al., 1989a). However, in both studies, the percentage of treated animals that ovulated was inconsistent and appeared to be related to the stage of the anoestrous season.

Recently, we reported that the number of antral follicles present in red deer hinds during the breeding season differed widely among individuals ( $4-81$ follicles $\geqslant 2 \mathrm{~mm}$ diameter per hind), and that the proportion of follicles that were healthy increased progressively over the follicular phase of the oestrous cycle (McLeod et al., 2001). Therefore, the reported variability in response to inductionsuperovulation treatments may simply reflect betweenanimal differences in the numbers of antral follicles present that are capable of responding to the exogenous hormones. The objective of the present study was to compare the responses to exogenous gonadotrophin (eCG) and to $\mathrm{GnRH}$-induced secretion of endogenous gonadotrophins, in promoting antral follicle development in the breeding and non-breeding seasons, to determine the underlying basis of seasonal differences in ovarian function in red deer. Some of these data (hinds treated with progesterone alone during the breeding season) were included in the earlier report of follicle populations in cyclic red deer hinds (McLeod et al., 2001).

\section{Materials and Methods}

\section{Animals and management}

A total of 55 parous adult red deer (Cervus elaphus) hinds, aged between 3 and 9 years, were used in this study. Ovaries were recovered from 40 of these animals during either the breeding season (March, $n=20$ ) or seasonal anoestrus (January, $n=20$ ). The remaining 15 hinds (control groups) were monitored on both of these occasions to determine the times of onset of oestrus and the preovulatory LH surge, so that the time of ovary recovery in their herdmates could be related to these endocrine events.

All hinds were maintained on pasture throughout the treatment period, with the exception that those animals from which ovaries were recovered were fasted overnight before ovariectomy or slaughter. All experimental procedures performed had been given prior approval by the AgResearch Invermay Animals Ethics Committee according to the Animals Protection (Codes of Ethical Conduct) Regulations, 1987.

\section{Treatment and blood sampling}

Oestrus was synchronized during the breeding season in the animals studied so that ovaries could be recovered at a known stage of the oestrous cycle. All hinds were subjected to exogenous progesterone treatment for 12 days, administered via controlled intravaginal drug releasing devices (EAZI-BREED CIDR, 0.3 g progesterone; InterAg, Hamilton). A single CIDR, left for 8 days in situ, was replaced with a fresh CIDR for the following 4 days to ensure that increased plasma progesterone concentrations were maintained throughout. All hinds treated during seasonal anoestrus were given an identical progesterone treatment, to allow unbiased comparison of follicle populations between the two reproductive states.

At the time of withdrawal of the second CIDR, hinds were assigned randomly to one of four treatment groups ( $n=5$ animals group). Animals in groups 1 and 2 (breeding season) and groups $1 \mathrm{a}$ and $2 \mathrm{a}$ (anoestrus) received no further treatment. Hinds in groups 3 (breeding season) and 3 a (anoestrus) were given a single i.m. injection of 300 iu eCG (Folligon; Intervet, Lane Cove, NSW) and those in groups 4 (breeding season) and 4 a (anoestrus) were treated with synthetic GnRH (Sigma, St Louis, MO) administered via osmotic minipumps (ALZET 2ML4; Alza Corp, Palo Alto, CA) at the rate of $1.0 \mu \mathrm{g} \mathrm{h}^{-1}$ for 4 days or until the time of ovariectomy. These treatment regimens are typical of those used in oestrus synchronization-superovulation programmes in red deer. Both the insertion and removal of minipumps was carried out under local anaesthetic $(2 \%$ $(\mathrm{w} / \mathrm{v})$ xylocaine hydrochloride), injected s.c. at the site of implantation in the neck region. Hinds that were to be blood sampled and monitored for oestrus and ovulation were included in all three treatment regimens (note that groups 1 and 2 received the same treatment). The same blood-sampled animals were assigned to the same treatment protocol in both the breeding and non-breeding seasons.

Ovaries were recovered from hinds ( $n=5$ per group) either at the time of (groups 1 and 1a), or approximately $36 \mathrm{~h}$ after the time of (groups 2, 2a, 3, 3a, 4 and 4a; Table 2) CIDR removal and follicle development within them was assessed. Ovaries were recovered either by ovariectomy 
carried out under barbiturate-induced and halothanemaintained anaesthesia or within minutes of death at slaughter at a registered deer slaughter facility (Otago Venison Ltd, Mosgiel).

Control animals were monitored for behavioural signs of oestrus and were blood sampled via an indwelling jugular vein catheter to determine the time of onset of the preovulatory LH surge. Blood samples were collected and observations of oestrus were made at $2 \mathrm{~h}$ intervals from $4 \mathrm{~h}$ before until $72 \mathrm{~h}$ after CIDR withdrawal as described by McLeod et al. (2001). The incidence of ovulation was determined in all these animals at laparoscopy, carried out 7 days after CIDR withdrawal under xylazine (Rompun; Bayer NZ Ltd, Petone, NZ) and fentanyl citrate plus azaperone (Fentaz: Smith, Kline and French (NZ) Ltd, Auckland) anaesthesia.

\section{Ovarian tissue collection and preparation}

Techniques used in the collection of ovarian tissue and analysis of follicle populations and their health status were as described by McLeod et al. (2001). Briefly, excised ovaries were placed immediately on ice in Dulbecco's PBS solution (KC Biological Inc., Lenaxa, KS), and transferred to an adjacent laboratory where they were weighed and all follicles $\geqslant 2.0 \mathrm{~mm}$ in diameter were dissected out under a stereomicroscope. After being dissected free of extraneous tissue, the diameter of each follicle was recorded (to the nearest $0.1 \mathrm{~mm}$ ) and follicle health was assessed. Follicular fluid was aspirated from each follicle, its volume measured and a sample snap-frozen for subsequent analysis of oestradiol content. Granulosa cells were harvested, washed and counted as described by McLeod et al. (2001).

\section{Granulosa cell aromatase activity and cAMP production}

Aromatase activity and CAMP production of the harvested granulosa cells was determined in vitro using the methods for deer follicles described by McLeod et al. (2001). Cells collected from each follicle were resuspended in ice-cold Dulbecco's PBS solution containing 0.1\% BSA (Sigma Chemical Company), $20 \mathrm{mmol}$ Hepes buffer $\mathrm{I}^{-1}$ and $0.2 \mathrm{mmol}$ 3-isobutyl-1-methylxanthine $\mathrm{I}^{-1}$ (Sigma; Medium A, $\mathrm{pH} 7.4,4.0^{\circ} \mathrm{C}$ ), with a final cell concentration of $2-4 \times 10^{5}$ cells $\mathrm{ml}^{-1}$. Aliquants $(0.5 \mathrm{ml}$, in duplicate or triplicate depending on the total number of granulosa cells recovered) of these cell suspensions were incubated to assess oestradiol (aromatase activity) or cAMP production.

For the determination of aromatase activity, cells were incubated in either medium alone (time zero incubations), or in medium containing $2.0 \mu \mathrm{g}$ testosterone $\mathrm{ml}^{-1}$ (testosterone incubations), both of which were made up to a final incubation volume of $1.0 \mathrm{ml}$. Time zero incubations were snap-frozen immediately at $-70^{\circ} \mathrm{C}$ and testosterone incubations were snap-frozen after incubation for $3 \mathrm{~h}$ at $37^{\circ} \mathrm{C}$ in a shaking water bath. All tubes were then stored at $-20^{\circ} \mathrm{C}$ until the media were assayed for oestradiol content.
Cell suspensions were incubated in either the media alone (time zero incubations), or in media containing $200 \mathrm{ng} \mathrm{LH}$ (NIH-LH-S17) $\mathrm{ml}^{-1}$ ( $\mathrm{LH}$ incubations), again made up to a final volume of $1.0 \mathrm{ml}$, and granulosa cell cAMP production was assessed. The $\mathrm{LH}$ incubations were placed in a shaking water bath at $37^{\circ} \mathrm{C}$ for $45 \mathrm{~min}$, after which time the reaction was stopped by immersion in a water bath at $80^{\circ} \mathrm{C}$ for $15 \mathrm{~min}$. Time zero incubations were immediately incubated at $80^{\circ} \mathrm{C}$ for $15 \mathrm{~min}$. All tubes were stored at $-20^{\circ} \mathrm{C}$ until the incubation media were assayed for cAMP.

Aromatase activity (expressed as ng oestradiol per $10^{6}$ cells $\mathrm{h}^{-1}$ ) and production rates of cAMP (mmol per $10^{6}$ cells $\mathrm{h}^{-1}$ ) in granulosa cells from individual follicles was calculated by subtracting the oestradiol or cAMP content of supernatant from time zero incubations from the values for the same follicle after the testosterone or LH incubations.

\section{Follicle classification}

Follicles were classified as healthy or atretic on the basis of the criteria described by McLeod et al. (2001), which had been adapted from the methods of McNatty et al. (1985) used for sheep follicles. The factors considered included the presence or absence of blood capillaries within the thecal tissue and of debris in the follicular fluid, the condition of the oocyte (healthy or degenerating, on the basis of the presence of a cumulus cell matrix, signs of cytolysis, necrosis or loss of spherical shape) and the total granulosa cell complement of the follicle.

Follicle health was classified as one of four categories (classes 1, 2a, 2b and 3) as described by McLeod et al. (2001). Only class 1 follicles are regarded as healthy (nonatretic), with those classed as classes $2 \mathrm{a}, 2 \mathrm{~b}$ and 3 representing follicles in progressive stages of degeneration and atresia. Non-atretic follicles were arbitrarily classified as 'oestrogenic', or 'non-oestrogenic' on the basis of their granulosa cell population, follicular fluid oestradiol content and aromatase activity and CAMP production (McLeod et al., 2001).

Follicles were described as having luteinized if they had a thickened, solid and opaque wall, with or without a fluidfilled cavity, and when there was no evidence of a rupture site.

\section{Hormone assays}

Plasma LH concentrations were determined using the heterologous double-antibody radioimmunoassay method described for deer plasma by Meikle and Fisher (1996). All samples were completed within one assay in which the intra-assay coefficient of variation was $11.7 \%$. The limit of detection was $0.08 \mathrm{ng} \mathrm{LH} \mathrm{ml}^{-1}$ plasma.

Concentrations of oestradiol in follicular fluid and in granulosa cell incubation media were measured using the tritiated oestradiol radioimmunoassay described for sheep by McNatty et al. (1981) and subsequently validated for deer (McLeod et al., 2001). Results were expressed as ng 
oestradiol per $10^{6}$ cells. Follicular fluid oestradiol was measured directly without extraction, in diluted (10-100

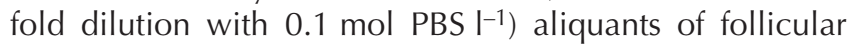
fluid. The limit of detection was $1.0 \mathrm{ng}$ oestradiol $\mathrm{ml}^{-1}$.

Granulosa cell cAMP production was determined using the method described by McNatty et al. (1985), and cAMP production was expressed as pmol per $10^{6}$ cells. Within this study, the inter- and intra-assay coefficients of variation were both $<10 \%$ and the limit of detection was $0.02 \mathrm{pmol}$ per $10^{6}$ cells.

\section{Statistical analyses}

The definition used to characterize a preovulatory $\mathrm{LH}$ surge was that there was a sustained $(>6 \mathrm{~h}$ ) increase of plasma $\mathrm{LH}$ concentrations above $2 \mathrm{ng} \mathrm{LH} \mathrm{m}^{-1}$ and that peak concentrations attained during this time exceeded $5 \mathrm{ng} \mathrm{ml}^{-1}$.

Comparison of follicle populations among treatment groups was made by analysis of variance, performed in conjunction with the Neuman and Keuls test, and of follicular fluid oestradiol content and granulosa cell hormone production rates by Student's $t$ test. The incidence of oestrus and ovulation was compared by chi-squared analysis, and changes in follicle health distribution, by cluster analysis. Unless otherwise stated, all values are presented as the mean \pm SEM.

\section{Results} Liveweights, oestrus, the preovulatory LH surge and
ovulation rates

There was no significant difference in mean liveweight between hinds treated during the breeding season $(n=35$, mean liveweight $100.1 \pm 2.0 \mathrm{~kg}$ ) and those treated in midanoestrus $(n=35$, mean liveweight $97.1 \pm 2.2 \mathrm{~kg}$ ). Both within and between seasons, there were no significant differences in liveweight among the treatment groups.

The mean incidence and the time of onset of oestrus and the preovulatory LH surge, and ovulation rates are shown for each of the groups of the blood-sampled hinds (Table 1). During the breeding season, four of five hinds treated with CIDRs alone and four of five eCG-treated hinds, but only two of five $\mathrm{GnRH}$-treated hinds, exhibited oestrus during the $76 \mathrm{~h}$ period of observation. A preovulatory LH surge was recorded in all except one hind (treated with CIDR alone), and all animals ovulated. When ovaries were observed by laparoscopy 7 days after CIDR withdrawal, two eCG-treated hinds had a double ovulation, and the remaining 13 animals each had ovulated a single follicle. Luteinized follicles were present in three hinds (all eCGtreated). There were no significant differences among treatment groups in the timing of oestrus or the preovulatory LH surge, or in ovulation rates.

When treated during seasonal anoestrus, none of the control animals subjected to CIDR alone or to $\mathrm{GnRH}$ exhibited oestrus, had a preovulatory LH surge or ovulated.
In contrast, four of five eCG-treated hinds were observed in oestrus and all these animals had a preovulatory surge. However, only two of these animals ovulated (single ovulation) and there was a luteinized follicle present on the ovaries of two hinds (one eCG-treated, one GnRH-treated) that had failed to ovulate.

\section{Antral follicle populations}

The mean times of ovary recovery are shown for each of the treatment groups (Table 2). In those animals in which the time of collection was nominally set at $36 \mathrm{~h}$, the mean time of recovery was $38.6 \pm 0.34 \mathrm{~h}$ after CIDR withdrawal. There were no significant differences in the mean recovery time among groups.

When all treatment groups are combined, the mean number of antral follicles $\geqslant 2.0 \mathrm{~mm}$ in diameter present did not differ significantly between the breeding (mean $19.6 \pm 2.81$, range $4-49$ follicles per hind) and nonbreeding seasons (mean $18.6 \pm 2.2$, range 10-39 follicles per hind). Similarly, the mean number of follicles present was not significantly different among groups in the breeding season (Table 2). However, hinds treated with GnRH during seasonal anoestrus had significantly more $(P<0.05)$ antral follicles than animals treated with CIDR alone in the same season or animals receiving the same treatment $(\mathrm{GnRH})$ in the breeding season. The numbers of large $(\geqslant 4.0 \mathrm{~mm}$ in diameter) follicles did not differ among treatment groups or between seasons.

\section{Follicle health status}

The mean number of healthy and oestrogenic follicles, and the mean diameter of the largest follicle, are shown (Table 3). With a single exception, the number of healthy follicles did not differ among treatments or between seasons. The exception was that the number of healthy follicles in animals treated with $\mathrm{GnRH}$ during the non-breeding season was significantly higher than it was in the other treatment groups at both reproductive states, and higher than it was in animals subjected to the same treatment during the breeding season. A similar trend was seen in the total number of oestrogenic follicles, but this was significant only between the GnRH-treated group and those treated with CIDRs alone in anoestrus. The number of hinds with at least one oestrogenic follicle present was not significantly different in either the breeding or non-breeding seasons (three of five versus two of five, three of five versus four of five, four of five versus five of five, four of five versus five of five for groups 1-4, respectively). There were no significant differences in the mean diameters of the largest healthy, or largest oestrogenic follicles present.

When animals from all treatment groups were combined and the health status of their follicles expressed as a percentage of all follicles present, there was a significantly higher proportion of healthy follicles present during seasonal anoestrus than during the breeding season $(72.2$ and $56.6 \%$ healthy, respectively, $P=0.019$, pooled $\mathrm{SD}=$ 
Table 1. Mean ( \pm SEM) times of onset of oestrus and the preovulatory LH surge and ovulation rates in red deer (blood-sampled hinds) treated with progesterone (CIDR) alone, or in conjunction with equine chorionic gonadotrophin (eCG) or GnRH during the breeding or non-breeding seasons

\begin{tabular}{lccc}
\hline & \multicolumn{2}{c}{ Time of onset (h after CIDR removal) } & \\
\cline { 2 - 3 } Treatment & Oestrus* & LH surge* & Ovulation rate* \\
\hline Breeding season & & & \\
CIDR alone & $45.0 \pm 5.8^{\mathrm{a}}(4 / 5)$ & $43.5 \pm 6.2^{\mathrm{a}}(4 / 5)$ & $1.0 \pm 0.0^{\mathrm{a}}(5 / 5)$ \\
CIDR plus eCG & $41.5 \pm 3.9^{\mathrm{a}}(4 / 5)$ & $39.2 \pm 4.1^{\mathrm{a}}(5 / 5)$ & $1.4 \pm 0.3^{\mathrm{a}}(5 / 5)$ \\
CIDR plus GnRH & $52.0 \pm 6.0^{\mathrm{a}}(2 / 5)$ & $41.6 \pm 5.5^{\mathrm{a}}(5 / 5)$ & $1.0 \pm 0.0^{\mathrm{a}}(5 / 5)$ \\
Seasonal anoestrus & $-(0 / 5)^{\mathrm{b}}$ & & $-(0 / 5)^{\mathrm{b}}$ \\
CIDR alone & $47.0 \pm 1.3^{\mathrm{a}}(4 / 5)$ & $45.5 \pm 1.0^{\mathrm{a}}(4 / 5)$ & $1.0 \pm 0.0^{\mathrm{a}}(2 / 5)$ \\
CIDR plus eCG & $-(0 / 5)^{\mathrm{b}}$ & $-(0 / 5)^{\mathrm{b}}$ & $-(0 / 5)^{\mathrm{b}}$ \\
CIDR plus GnRH & & & \\
\hline
\end{tabular}

* Numbers in parentheses show the numbers of hinds in each group in which oestrus, an LH surge and ovulation were recorded.

Within columns, values with different superscripts are significantly different $(P<0.05)$.

Table 2. Mean times of ovary recovery and total number of antral follicles in red deer hinds $(n=5$ per group) treated with progesterone (CIDR) alone, or in conjunction with equine chorionic gonadotrophin (eCG) or GnRH during the breeding or non-breeding seasons

\begin{tabular}{|c|c|c|c|c|}
\hline \multirow[b]{2}{*}{ Group } & \multirow[b]{2}{*}{ Treatment } & \multirow{2}{*}{$\begin{array}{l}\text { Ovary recovery time } \\
\text { (h from CIDR withdrawal) }\end{array}$} & \multicolumn{2}{|c|}{ Total number of follicles* } \\
\hline & & & $\geqslant 2.0 \mathrm{~mm}$ & $\geqslant 4.0 \mathrm{~mm}$ \\
\hline \multicolumn{5}{|c|}{ Breeding season } \\
\hline 1 & CIDR alone $(0 \mathrm{~h})$ & $0 \pm 0.0^{\mathrm{a}}$ & $22.8 \pm 8.22^{\mathrm{ab}}(4-49)$ & $2.6 \pm 0.40^{\mathrm{a}}(2-4)$ \\
\hline 2 & CIDR alone (36 h) & $38.9 \pm 0.36^{b}$ & $23.0 \pm 6.86^{\mathrm{ab}}(6-39)$ & $3.8 \pm 0.97^{a}(1-7)$ \\
\hline 3 & CIDR/eCG & $37.6 \pm 0.76^{b}$ & $17.6 \pm 4.24^{\mathrm{ab}}(5-31)$ & $4.2 \pm 1.53^{\mathrm{a}}(1-10)$ \\
\hline 4 & CIDR/GnRH & $38.8 \pm 0.61^{b}$ & $14.2 \pm 4.82^{\mathrm{a}}(4-32)$ & $3.4 \pm 0.51^{\mathrm{a}}(3-5)$ \\
\hline \multicolumn{5}{|c|}{ Seasonal anoestrus } \\
\hline $1 \mathrm{a}$ & CIDR alone $(0 \mathrm{~h})$ & $0 \pm 0.0^{\mathrm{a}}$ & $11.2 \pm 0.58^{\mathrm{a}}(10-13)$ & $3.2 \pm 1.32^{\mathrm{a}}(1-8)$ \\
\hline $2 a$ & CIDR alone (36 h) & $38.5 \pm 0.56^{b}$ & $13.8 \pm 1.28^{\mathrm{a}}(10-17)$ & $3.0 \pm 0.55^{\mathrm{a}}(1-4)$ \\
\hline $3 a$ & CIDR/eCG & $38.1 \pm 0.64^{b}$ & $20.2 \pm 4.38^{\mathrm{ab}}(10-36)$ & $3.0 \pm 0.55^{\mathrm{a}}(1-4)$ \\
\hline $4 a$ & $\mathrm{CIDR} / \mathrm{GnRH}$ & $38.7 \pm 0.52^{b}$ & $29.2 \pm 4.80^{b}(12-39)$ & $6.2 \pm 1.66^{\mathrm{a}}(1-10)$ \\
\hline
\end{tabular}

*Numbers in parentheses represent the range in numbers of follicles per hind.

Within columns, values with different superscripts are significantly different $(P<0.05)$.

3.51). The percentage of follicles in each health class is shown for individual treatment groups (Fig. 1). The distribution of atretic follicles across the three classes was significantly different $(P<0.05)$ between seasons (anoestrus: 19.4, 9.6 and $0.1 \%$; breeding season: $11.2,25.5$ and $6.8 \%$ for classes $2 \mathrm{a}, 2 \mathrm{~b}$ and 3 , respectively), but not among treatment groups.

\section{Oestradiol and CAMP production}

Mean concentrations of oestradiol in the follicular fluid of oestrogenic follicles, and in vitro oestradiol (aromatase activity) and cAMP production by their granulosa cells, are shown (Table 4). During both seasons, oestradiol content of follicular fluid was significantly higher $(P<0.05)$ in $\mathrm{GnRH}$ treated animals than in hinds treated with CIDRs alone.
Follicular fluid concentrations in eCG-treated hinds were midway between these two groups. Neither aromatase activity nor cAMP production differed significantly among groups or between seasons.

\section{Discussion}

Treatment with exogenous gonadotrophin (eCG) or inducing endogenous gonadotrophin secretion (with $\mathrm{GnRH}$ ) promoted antral follicle development in red deer hinds, increasing the number of oestrogenic follicles present and their follicular fluid oestradiol content in both the breeding and nonbreeding seasons. However, the response was variable and it is likely that few of these follicles would have successfully completed preovulatory development and ovulated. These 
Table 3. Mean ( \pm SEM) number of healthy and oestrogenic follicles, and the mean diameter of the largest follicle present, in red deer hinds treated with progesterone (CIDR) alone, or in conjunction with equine chorionic gonadotrophin (eCG) or GnRH during the breeding or non-breeding seasons

\begin{tabular}{|c|c|c|c|c|c|}
\hline \multirow[b]{2}{*}{ Group } & \multirow[b]{2}{*}{ Treatment } & \multirow{2}{*}{$\begin{array}{l}\text { Number of healthy } \\
\text { follicles* }\end{array}$} & \multirow{2}{*}{$\begin{array}{c}\text { Number of } \\
\text { oestrogenic follicles* }\end{array}$} & \multicolumn{2}{|c|}{ Mean diameter $(\mathrm{mm})$ of largest follicle } \\
\hline & & & & Healthy & Oestrogenic \\
\hline \multicolumn{6}{|c|}{ Breeding season } \\
\hline 1 & CIDR alone (0 h) & $8.0 \pm 1.64^{\mathrm{a}}(4-13)$ & $0.8 \pm 0.37^{\mathrm{a}}(0-2)$ & $7.5 \pm 0.33^{a}$ & $7.7 \pm 0.33^{a}$ \\
\hline 2 & CIDR alone $(36 \mathrm{~h})$ & $9.0 \pm 2.47^{\mathrm{a}}(3-18)$ & $1.0 \pm 0.45^{\mathrm{a}}(0-2)$ & $8.0 \pm 0.63^{a}$ & $6.3 \pm 0.76^{\mathrm{a}}$ \\
\hline 3 & CIDR/eCG & $8.4 \pm 2.46^{\mathrm{a}}(3-16)$ & $2.0 \pm 0.71^{\mathrm{ac}}(0-4)$ & $8.0 \pm 1.04^{\mathrm{a}}$ & $9.0 \pm 0.33^{a}$ \\
\hline 4 & $\mathrm{CIDR} / \mathrm{GnRH}$ & $8.0 \pm 2.35^{\mathrm{a}}(1-14)$ & $1.8 \pm 0.58^{\mathrm{ac}}(0-3)$ & $7.8 \pm 0.88^{\mathrm{a}}$ & $8.2 \pm 0.94^{\mathrm{a}}$ \\
\hline \multicolumn{6}{|c|}{ Seasonal anoestrus } \\
\hline $1 \mathrm{a}$ & CIDR alone (0 h) & $8.6 \pm 0.75^{\mathrm{a}}(7-11)$ & $0.4 \pm 0.24^{\mathrm{a}}(0-1)$ & $7.4 \pm 0.42^{\mathrm{a}}$ & $7.3 \pm 0.35^{\mathrm{a}}$ \\
\hline $2 \mathrm{a}$ & CIDR alone $(36 \mathrm{~h})$ & $9.0 \pm 1.05^{\mathrm{a}}(7-12)$ & $0.8 \pm 0.20^{\mathrm{ab}}(0-1)$ & $7.9 \pm 0.25^{a}$ & $7.9 \pm 0.27^{a}$ \\
\hline $3 a$ & CIDR/eCG & $11.0 \pm 0.84^{\mathrm{a}}(9-14)$ & $1.4 \pm 0.24^{\mathrm{bc}}(1-2)$ & $9.3 \pm 0.64^{\mathrm{a}}$ & $9.0 \pm 0.87^{a}$ \\
\hline $4 a$ & CIDR/GnRH & $23.6 \pm 4.38^{b}(7-33)$ & $2.6 \pm 0.68^{\mathrm{c}}(1-4)$ & $7.7 \pm 0.77^{a}$ & $7.7 \pm 0.77^{a}$ \\
\hline
\end{tabular}

*Numbers in parentheses represent the range in numbers of follicles per hind.

Within columns, values with different superscripts are significantly different $(P<0.05)$.

hormonal treatments resulted in a double ovulation in only two of the blood-sampled animals in the breeding season and only two of ten animals had an induced ovulation when treated in seasonal anoestrus. There were surprisingly few between-season differences in the parameters of follicle development monitored.

The ovulation rates observed in the hinds in the present study are not dissimilar to those reported previously for a variety of cervid species subjected to these treatments. Comparable doses of eCG administered during or within a few weeks of the start of the breeding season have resulted in double ovulations in $10-50 \%$ of treated red and fallow deer (Fisher et al., 1989a; Asher et al., 1992). Multiple ovulations $(>2$ ) can be induced in deer with higher doses of eCG (Kelly et al., 1982; Asher and Smith 1987). At least $50 \%$ of treated animals ovulated a single follicle when GnRH was administered 3-6 weeks before the start of the breeding season (red deer: Fisher et al., 1989a,b; fallow deer: Asher and Macmillan, 1986; Père David's deer: McLeod et al., 1991). However, few if any hinds ovulated when treated in mid-anoestrus (McLeod et al., 1991). There are also reports of seasonal variation in the ovulatory response to treatment with exogenous gonadotrophins in other species. For example, when sheep were subjected to repeated injections of low doses of $\mathrm{LH}$ for an extended period, $100 \%$ ovulated when treated in early anoestrus, but only $25 \%$ ovulated when treated in mid-anoestrus (Oussaid et al., 1998).

The times of onset of oestrus and of the preovulatory LH surge recorded in the blood-sampled hinds in the present study are similar to those reported earlier in red deer (Asher et al., 1992). They also indicate that follicle collection from the experimental animals would have occurred at a stage equivalent to late follicular phase before occurrence of the LH surge. The time of onset of oestrus and the preovulatory
LH surge, both events that are initiated by increasing plasma oestradiol concentrations, was not influenced by treatment with exogenous gonadotrophins. This was in contrast to previous reports in sheep in which there was an inverse relationship between the time of onset of oestrus and ovulation and dose of eCG (Boshoff et al., 1973).

The mean number of large antral follicles recorded in hinds in this study (range 1-10 per hind) was similar to that recorded by ultrasonography in red deer hinds during the breeding season (Asher et al., 1997). In both the present study and that of Asher et al. (1997), there were no significant differences in the numbers of antral follicles present in the breeding season compared with seasonal anoestrus. This finding is in contrast to the findings in sheep reported by McNatty et al. (1984) in which significantly more antral follicles $\geqslant 1 \mathrm{~mm}$ in diameter were present during seasonal anoestrus than during the breeding season. In the present study, there were seasonal changes in the proportion of healthy follicles in untreated hinds (CIDRalone groups), with follicle populations being skewed towards class 1 (non-atretic) in anoestrus and towards classes $2 \mathrm{~b}$ and 3 (advanced atresia) in the breeding season. Treatment with gonadotrophins during seasonal anoestrus tended to alter follicle health status towards that seen in the breeding season. Similar seasonal changes in follicle health distribution have previously been reported in sheep (McNatty et al., 1984).

The increase in follicular fluid oestradiol concentrations observed in the gonadotrophin-treated hinds concurs with the pattern reported in both sheep (McNatty et al., 1982) and pigs (Miller et al., 1999) treated with eCG. The increased oestradiol concentrations did not promote the time of onset of oestrus or the onset of the preovulatory $\mathrm{LH}$ surge but rather there appeared to be adverse effects on oestrous behaviour, with four of ten of the gonadotrophin- 
(a)

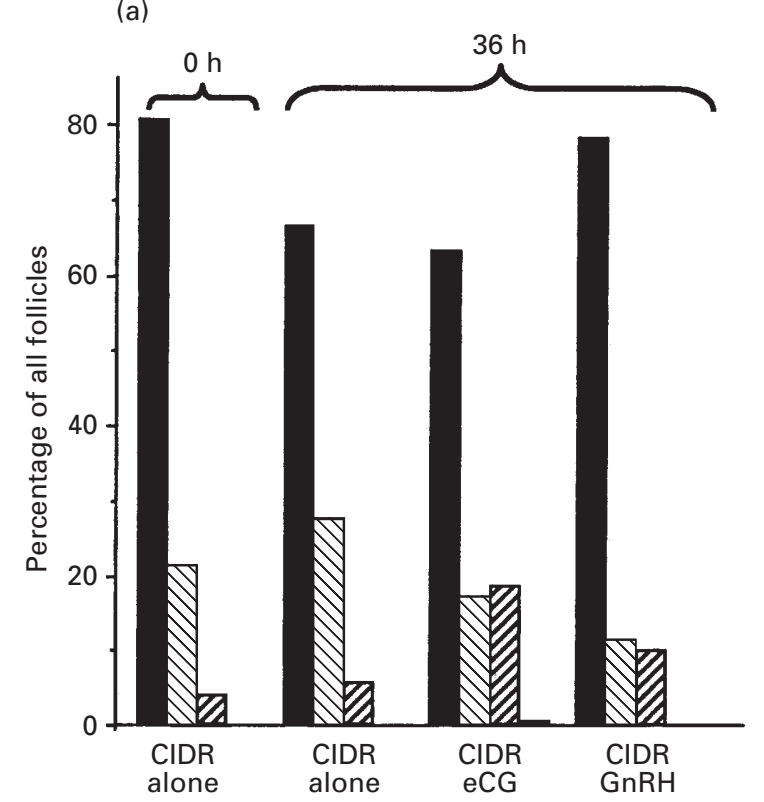

(b)

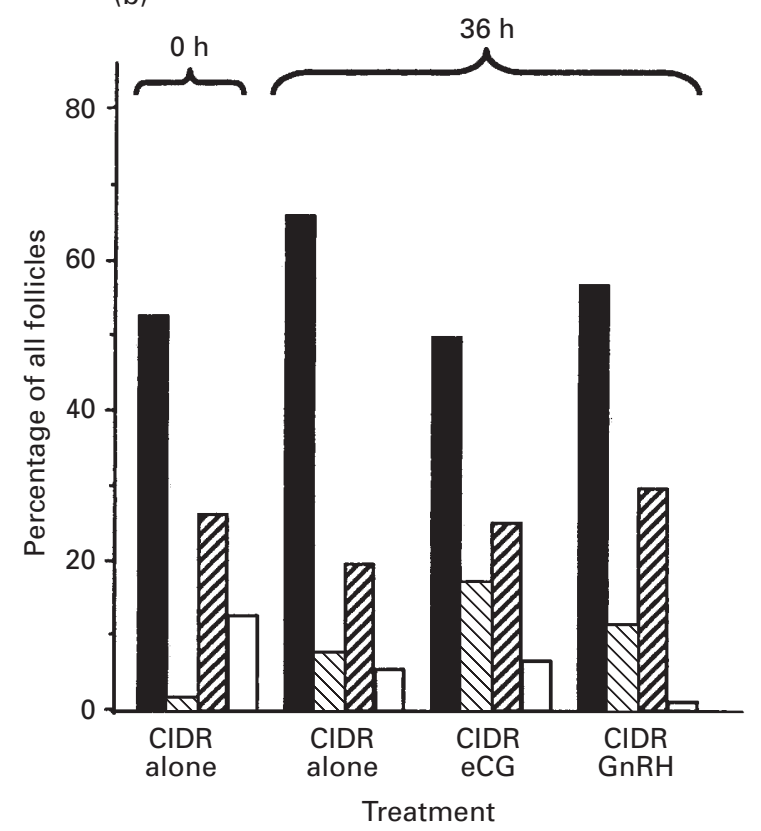

Fig. 1. Percentage of antral follicles $\geqslant 2 \mathrm{~mm}$ in diameter in each

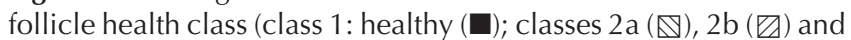
$3(\square)$ : progressive stages of atresia) in ovaries recovered from red deer hinds either at the time of $(0 \mathrm{~h})$, or $36 \mathrm{~h}$ after, removal of progesterone during the (a) anoestrus or (b) breeding seasons.

treated control hinds failing to exhibit oestrus in the breeding season, although they all ovulated. In addition, despite the significant increase in the number of oestrogenic follicles present, and in their oestradiol content, evident in their experimental counterparts, none of the $\mathrm{GnRH}$-treated hinds that were blood sampled displayed oestrus, produced a preovulatory LH surge or ovulated when treated during seasonal anoestrus. Meikle and Fisher (1991) showed that a single injection of oestradiol after pretreatment with progesterone induced both an LH surge and oestrus in longterm ovariectomized hinds during anoestrus, except when the treatment was given in mid-anoestrus (January). This is the same time of year in which the seasonal anoestrus experiment was carried out in the present study, in which only four of ten gonadotrophin-treated hinds displayed oestrus and had a preovulatory LH surge, and only two of ten ovulated. It remains to be determined whether the same treatment regimens would promote follicle development and induce oestrus and ovulation at other stages of seasonal anoestrus.

A further abnormality in ovarian function observed in gonadotrophin-treated hinds, was the luteinization of large antral follicles in the blood-sampled animals. Luteinized follicles were observed in five hinds (three breeding season, two anoestrus) in which gonadotrophins had been manipulated. Asher and Smith (1987) reported the occurrence of luteinized follicles in over $50 \%$ of fallow deer treated with eCG, and this phenomenon has also been described in sheep treated with GnRH (Gilbert et al., 1990). Luteinization of large antral follicles occurs typically at a very low rate in both red and fallow deer treated with CIDRs alone $(<1 \%, n>300$, G. W. Asher and I. C. Scott, unpublished) but does appear to be a consequence of the administration of exogenous gonadotrophins. In rats, a single injection of a low dose of exogenous LH given some hours before the expected time of the preovulatory LH surge results in luteinization without ovulation in virtually all of the Graafian follicles present (Mattheij and Swarts, 1995). A cytokine (vascular endothelial growth factor) that induces angiogenesis, which is a feature of follicle luteinization, has been proposed as the mediator of luteinization in women (Anasti et al., 1998), and its production in primate preovulatory follicles is induced by LH (Hazzard et al., 1999).

Despite the incidence of follicle luteinization in the blood-sampled hinds, no luteinized follicles were present in ovaries recovered from the experimental animals. These hinds would have been exposed to exogenous gonadotrophins for a period of $<40 \mathrm{~h}$ and the ovaries were recovered before the onset of the preovulatory LH surge, which presumably triggers luteinization.

In summary, manipulating plasma gonadotrophin concentrations in hinds during either the breeding or nonbreeding season influences follicle development, but does not change the number of antral follicles that enter the growing phase or the size distribution of the antral follicle population. Nevertheless, the extent to which this promotion of antral follicle growth results in the development of healthy, oestrogenic follicles varies widely among individual animals in both the breeding and non-breeding seasons. This variability is probably a reflection of the numbers of healthy antral follicles present at the time of treatment. As a consequence of this variability, the number of follicles that ovulate will be variable and unpredictable. 
Table 4. Mean ( \pm SEM) diameter, follicular fluid oestradiol concentration and granulosa cell aromatase activity and cAMP production of oestrogenic follicles recovered from red deer hinds treated with progesterone (CIDR) alone, or in conjunction with equine chorionic gonadotrophin (eCG) or GnRH during the breeding or non-breeding seasons

\begin{tabular}{|c|c|c|c|c|c|c|}
\hline \multirow[b]{2}{*}{ Group } & \multirow[b]{2}{*}{ Treatment } & \multirow[b]{2}{*}{$n$} & \multirow[b]{2}{*}{$\begin{array}{l}\text { Follicle diameter } \\
\qquad(\mathrm{mm})\end{array}$} & \multirow[b]{2}{*}{$\begin{array}{c}\text { Follicle fluid } \\
\text { oestradiol }\left(\mathrm{ng} \mathrm{ml}^{-1}\right)\end{array}$} & \multicolumn{2}{|c|}{ Granulosa cell } \\
\hline & & & & & $\begin{array}{l}\text { Aromatase (ng per } \\
\left.10^{6} \text { cells }^{-1}\right)\end{array}$ & $\begin{array}{c}\text { cAMP }\left(\text { pmol per } 10^{6}\right. \\
\left.\text { cells } \mathrm{h}^{-1}\right)\end{array}$ \\
\hline \multicolumn{7}{|c|}{ Breeding season } \\
\hline 1 & CIDR alone $(0 \mathrm{~h})$ & 4 & $7.4 \pm 0.4$ & $79.7 \pm 14.5^{\mathrm{a}}$ & $10.8 \pm 0.1^{\mathrm{a}}$ & $5.8 \pm 4.2^{\mathrm{a}}$ \\
\hline 2 & CIDR alone (36 h) & 5 & $5.8 \pm 0.6$ & $85.1 \pm 18.9^{a}$ & $7.1 \pm 1.9^{a}$ & $4.8 \pm 3.2^{\mathrm{a}}$ \\
\hline 3 & CIDR/eCG & 10 & $5.6 \pm 0.9$ & $120.1 \pm 18.3^{\mathrm{ab}}$ & $7.5 \pm 1.5^{\mathrm{a}}$ & $10.2 \pm 4.7^{\mathrm{a}}$ \\
\hline 4 & $\mathrm{CIDR} / \mathrm{GnRH}$ & 9 & $5.6 \pm 0.9$ & $158.8 \pm 31.4^{b}$ & $5.8 \pm 1.2^{\mathrm{a}}$ & $6.5 \pm 1.5^{\mathrm{a}}$ \\
\hline \multicolumn{7}{|c|}{ Seasonal anoestrus } \\
\hline $1 \mathrm{a}$ & CIDR alone $(0 \mathrm{~h})$ & 2 & $7.3 \pm 0.2$ & $89.4 \pm 16.4^{\mathrm{a}}$ & $7.1 \pm 2.3^{\mathrm{a}}$ & $0.4 \pm 0.24^{\mathrm{a}}$ \\
\hline $2 \mathrm{a}$ & CIDR alone (36 h) & 4 & $7.9 \pm 0.3$ & $167.9 \pm 29.5^{\mathrm{a}}$ & $8.9 \pm 2.1^{\mathrm{a}}$ & $0.8 \pm 0.20^{\mathrm{a}}$ \\
\hline 3a & CIDR/eCG & 7 & $7.6 \pm 1.1$ & $264.8 \pm 49.3^{\mathrm{ab}}$ & $8.6 \pm 1.8^{\mathrm{a}}$ & $1.4 \pm 0.24^{\mathrm{a}}$ \\
\hline $4 a$ & $\mathrm{CIDR} / \mathrm{GnRH}$ & 13 & $5.8 \pm 0.5$ & $293.5 \pm 37.6^{\mathrm{b}}$ & $8.7 \pm 1.9^{a}$ & $2.6 \pm 0.68^{\mathrm{a}}$ \\
\hline
\end{tabular}

Within columns, values with different superscripts are significantly different $(P<0.05)$.

Most importantly, these treatments are often associated with abnormalities in follicle development that may result in luteinization without ovulation.

The authors wish to thank Dr Colin Mackintosh for assistance with surgery, the staff of the Invermay Deer Unit for assistance with all aspects of deer handling and sample collection and the Pituitary Hormone Distribution Program, NIADDK, NIH, Baltimore, MD, USA for the pituitary hormone and radioimmunoassay kits.

\section{References}

Adams CL, Moir CE and Atkinson T (1985) Plasma concentrations o progesterone in female red deer (Cervus elaphus) during the breeding season, pregnancy and anoestrus Journal of Reproduction and Fertility 74 631-636

Anasti JN, Kalantaridou SN, Kimzey LM, George M and Nelson LM (1998 Human follicle fluid vascular endothelial growth factor concentrations are correlated with luteinization in spontaneously developing follicles Human Reproduction 13 1144-1147

Asher GW and Macmillan (1986) Induction of oestrus and ovulation in anoestrous fallow deer (Dama dama) by using progesterone and $\mathrm{GnRH}$ treatment Journal of Reproduction and Fertility 81 113-118

Asher GW and Smith JF (1987) Induction of oestrus and ovulation in farmed fallow deer (Dama dama) by using progesterone and PMSG treatment Journal of Reproduction and Fertility 81 113-118

Asher GW, Fisher MW, Jabbour HN, Smith JF, Mulley RC, Morrow CJ, Veldhuizen FA and Langridge M (1992) Relationship between the onset of oestrus, the preovulatory surge in luteinizing hormone and ovulation following oestrous synchronization and superovulation of farmed red deer (Cervus elaphus) Journal of Reproduction and Fertility 96 261-273

Asher GW, Jabbour HN, Thompson JGE, Tervit HR and Morrow CJ (1995) Superovulation of farmed red deer (Cervus elaphus) and fallow deer (Dama dama): incidence of ovulation and changes in plasma hormone concentrations during the pre-ovulatory period in relation to ova recovery and fertilisation Animal Reproduction Science 38 135-154

Asher GW, Fisher MW and Fennessey PF (1996) Environmental constraints on reproductive performance of farmed deer Animal Reproduction Science 42 35-44

Asher GW, Scott IC, O'Neill KT, Smith JF, Inskeep EK, Townsend EC (1997)
Ultrasonographic monitoring of antral follicle development in red deer (Cervus elaphus) Journal of Reproduction and Fertility 111 91-99

Boshoff DA, Niekerk CH van, Morgenthal JC (1973) Time of ovulation in the Karakul ewe following synchronization of oestrus South African Journal of Animal Science 3 13-17

Dott HM, Hay MF, Cran DG and Moor RM (1979) Effect of exogenous gonadotrophin (PMSG) on the antral follicle population in the sheep Journal of Reproduction and Fertility 56 683-689

Fennessey PF, Asher GW, Beatson NS, Dixon TE, Hunter JW and Bringans MJ (1994) Embryo transfer in deer Theriogenology 41 133-138

Fisher MW, Fennessey PF and Davis GH (1989a) A note on the induction of ovulation in lactating red deer hinds prior to the breeding season Animal Production 49 134-138

Fisher MW, Fennessey PF, Corson ID, Pearse AJT, Davis GH and Johnstone PD (1989b) Early induction of ovulation in yearling red deer hinds Proceedings New Zealand Society of Animal Production 46 171-173

Gilbert CL, Hunter MG, Southee JA, and Wathes DC (1990) Immunocytochemical localization of oxytocin in corpora lutea and luteinized cysts from anoestrous ewes stimulated with gonadotrophin-releasing hormone Cell Tissue Research 262 157-164

Hazzard TM, Molskness TA, Chaffin CL and Stouffer RL (1999) Vascula endothelial growth factor (VEGF) and angiopoietin regulation by gonadotrophin and steroids in macaque granulosa cell during the periovulatory interval Molecular Human Reproduction 12 1115-1121

Hirschfield AN (1991) Development of follicles in the mammalian ovary International Reviews of Cytology 124 43-101

Hoffman RR (1985) Digestive physiology of the deer - their morphological specialisation and adaptation. In Biology of Deer Production pp 393-408 Eds PF Fennessey and KR Drew. The Royal Society of New Zealand, Wellington

Kelly RW, McNatty KP, Moore GH, Ross D and Gibb M (1982) Plasma concentrations of $\mathrm{LH}$, prolactin, oestradiol and progesterone in female red deer (Cervus elaphus) during pregnancy Journal of Reproduction and Fertility 64 475-483

Lincoln GA and Short RV (1980) Seasonal breeding: nature's contraceptive Recent Progress in Hormone Research 36 1-52

McGee EA and Hsueh AJW (2000) Initial and cyclic recruitment of ovarian follicles Endocrine Reviews 21 200-214

McLeod BJ, Haresign W and Lamming GE (1982) Response of seasonally anoestrous ewes to small-dose multiple injections of $\mathrm{GnRH}$ with and without progesterone pretreatment Journal of Reproduction and Fertility $65223-230$ 
McLeod BJ, Haresign W and Lamming GE (1983) Induction of ovulation in seasonally anoestrous ewes by continuous infusion of low doses of GnRH Journal of Reproduction and Fertility 68 489-495

McLeod BJ, Brinklow BR, Curlewis JD and Loudon ASI (1991) Efficacy of intermittent or continuous administration of $\mathrm{GnRH}$ in inducing ovulation in early and late seasonal anoestrus in the Père David's deer hind (Elaphurus davidianus) Journal of Reproduction and Fertility $\mathbf{9 1}$ 229-238

McLeod BJ, Meikle LM, Heath DA, McNatty KP and Fisher MW (2001) Variation in antral follicle development over the follicular phase of the oestrous cycle in the red deer hind Reproduction 120 211-216

McNatty KP and Henderson KM (1987) Gonadotrophins, fecundity genes and ovarian follicular function Journal Steroid Biochemistry 27 365-373

McNatty KP, Gibb M, Dobson C, Thurley DC and Findlay JK (1981) Changes in the concentrations of gonadotrophic and steroidal hormones in the antral fluid of ovarian follicles throughout the oestrous cycle of the sheep Australian Journal of Biological Sciences 34 67-80

McNatty KP, Gibb M, Dobson C, Ball K, Coster J, Heath D and Thurley DC (1982) Preovulatory follicle development in sheep treated with PMSG and/or prostaglandin Journal of Reproduction and Fertility 55 111-123

McNatty KP, Hudson NL, Henderson KM, Lun S, Heath DA, Gibb M, Ball K, McDiarmid JM and Thurley DC (1984) Changes in gonadotrophin secretion and ovarian antral follicular activity in seasonally breeding sheep throughout the year Journal of Reproduction and Fertility 70 309-321
McNatty KP, Henderson KM, Lun S, Heath DA, Ball K, Hudson NL, Fannin J, Gibb M, Kieboom LE and Smith P (1985) Ovarian activity in Booroola $\times$ Romney ewes have a major gene influencing ovulation rate Journal of Reproduction and Fertility 73 109-120

Mattheij JA and Swarts HJ (1995) Induction of luteinized unruptured follicles in the rat after injection of luteinizing hormone early in prooestrus European Journal of Endocrinology 132 91-96

Meikle LM and Fisher MW (1991) Induction of oestrus in ovariectomised red deer with exogenous progesterone and oestradiol benzoate Proceedings New Zealand Society of Animal Production 50 155-159

Meikle LM and Fisher MW (1996) Regulation of seasonality in the red deer hind: oestradiol-dependent and -independent influences on the patterns of LH concentrations Journal of Reproduction and Fertility 106 213-220

Miller AT, Picton HM and Hunter MG (1999) Suppression of ovarian activity in the gilt and reversal by exogenous gonadotrophin administration Animal Reproduction Science 54 179-193

Oussaid B, Cognie Y and Mariana JC (1998) Ovarian stimulation following repeated injections of $\mathrm{LH}$ or $\mathrm{LH}+\mathrm{FSH}$ in Ile-de-France sheep in early and mid-seasonal anoestrus Animal Reproduction Science 31 83-98

Received 21 December 2000.

First decision 7 February 2001.

Accepted 27 March 2001. 